\begin{abstract}
Iranica
Abstracta Iranica Revue bibliographique pour le domaine irano-aryen

Volume 32-33 | 2013

Comptes rendus des publications de 2009-2010
\end{abstract}

\title{
Michaël G. Morony. Christians in Iraq after the Muslim Conquest
}

\section{Christelle Jullien}

\section{(2) OpenEdition}

1 Journals

\section{Édition électronique}

URL : http://journals.openedition.org/abstractairanica/40859

DOI : 10.4000/abstractairanica.40859

ISSN : 1961-960X

Éditeur :

CNRS (UMR 7528 Mondes iraniens et indiens), Éditions de l'IFRI

\section{Édition imprimée}

Date de publication : 1 décembre 2013

ISSN : 0240-8910

\section{Référence électronique}

Christelle Jullien, « Michaël G. Morony. Christians in Iraq after the Muslim Conquest », Abstracta Iranica [En ligne], Volume 32-33 | 2013, document 339, mis en ligne le 01 juillet 2016, consulté le 26

septembre 2020. URL : http://journals.openedition.org/abstractairanica/40859; DOI : https://doi.org/ $10.4000 / a b s t r a c t a i r a n i c a .40859$

Ce document a été généré automatiquement le 26 septembre 2020.

Tous droits réservés 


\title{
Michaël G. Morony. Christians in Iraq after the Muslim Conquest
}

\author{
Christelle Jullien
}

\section{RÉFÉRENCE}

Michaël G. Morony. Christians in Iraq after the Muslim Conquest. Piscataway NJ, Gorgias Press, 2009, 52 p. (Analecta Gorgiana, 111)

1 Second volet de cette réimpression sélective, celui qui concerne les chrétiens après la conquête arabe (reprise des p. 332-383). On y retrouve la présentation du rôle politique de l'Église sous les Sassanides et des tensions avec la religion officielle mazdéenne, mais aussi des forces politiques internes au sein des communautés chrétiennes. L'A. développe sa position historique sur la tolérance du christianisme sous la juridiction musulmane.

\section{AUTEURS}

\section{CHRISTELLE JULLIEN}

CNRS, Mondes iranien et indien, Paris 